\title{
Prostate stem cell antigen interacts with nicotinic acetylcholine receptors and is affected in Alzheimer's disease
}

Jensen, Majbrit Myrup; Mikkelsen, Jens D.; Arvaniti, Maria; Pinborg, Lars Hageman; Thomsen, Morten Skøtt

Published in:

Neurobiology of Aging

DOI:

10.1016/j.neurobiolaging.2015.01.001

Publication date:

2015

Citation for published version (APA):

Jensen, M. M., Mikkelsen, J. D., Arvaniti, M., Pinborg, L. H., \& Thomsen, M. S. (2015). Prostate stem cell

antigen interacts with nicotinic acetylcholine receptors and is affected in Alzheimer's disease. Neurobiology of Aging, 36(4), 1629-1638. https://doi.org/10.1016/j.neurobiolaging.2015.01.001 


\title{
Prostate stem cell antigen interacts with nicotinic acetylcholine receptors and is affected in Alzheimer's disease
}

\author{
Majbrit M. Jensen ${ }^{\mathrm{a}}$, Maria Arvaniti ${ }^{\mathrm{a}}$, Jens D. Mikkelsen ${ }^{\mathrm{a}}$, Dominik Michalski ${ }^{\mathrm{b}}$, \\ Lars H. Pinborg ${ }^{\mathrm{a}, \mathrm{c}}$, Wolfgang Härtig ${ }^{\mathrm{d}}$, Morten S. Thomsen ${ }^{\mathrm{a}, *}$ \\ ${ }^{a}$ Neurobiology Research Unit, Copenhagen University Hospital, Rigshospitalet, Copenhagen, Denmark \\ ${ }^{\mathrm{b}}$ Department of Neurology, University of Leipzig, Leipzig, Germany \\ ${ }^{\mathrm{c}}$ Epilepsy Clinic, Copenhagen University Hospital, Rigshospitalet, Copenhagen, Denmark \\ ${ }^{\mathrm{d}}$ Paul Flechsig Institute for Brain Research, University of Leipzig, Leipzig, Germany
}

\section{A R T I C L E I N F O}

\section{Article history:}

Received 2 July 2014

Received in revised form 8 December 2014

Accepted 3 January 2015

Available online 7 January 2015

\section{Keywords:}

Alzheimer's disease

Nicotinic acetylcholine receptor

Frontal cortex

Lynx

PSCA

Lypd6

\begin{abstract}
A B S T R A C T
Alzheimer's disease (AD) is a neurodegenerative disorder involving impaired cholinergic neurotransmission and dysregulation of nicotinic acetylcholine receptors (nAChRs). Ly-6/neurotoxin (Lynx) proteins have been shown to modulate cognition and neural plasticity by binding to nAChR subtypes and modulating their function. Hence, changes in nAChR regulatory proteins such as Lynx proteins could underlie the dysregulation of $\mathrm{nAChRs}$ in $\mathrm{AD}$. Using Western blotting, we detected bands corresponding to the Lynx proteins prostate stem cell antigen (PSCA) and Lypd6 in human cortex indicating that both proteins are present in the human brain. We further showed that PSCA forms stable complexes with the $\alpha 4$ nAChR subunit and decreases nicotine-induced extracellular-signal regulated kinase phosphorylation in PC12 cells. In addition, we analyzed protein levels of PSCA and Lypd6 in postmortem tissue of medial frontal gyrus from AD patients and found significantly increased PSCA levels (approximately 70\%). In contrast, no changes in Lypd6 levels were detected. In concordance with our findings in AD patients, PSCA levels were increased in the frontal cortex of triple transgenic mice with an AD-like pathology harboring human transgenes that cause both age-dependent $\beta$-amyloidosis and tauopathy, whereas Tg2576 mice, which display $\beta$-amyloidosis only, had unchanged PSCA levels compared to wild-type animals. These findings identify PSCA as a nAChR-binding protein in the human brain that is affected in $A D$, suggesting that PSCA-nAChR interactions may be involved in the cognitive dysfunction observed in $\mathrm{AD}$.
\end{abstract}

(c) 2015 Elsevier Inc. All rights reserved.

\section{Introduction}

Alzheimer's disease (AD) is the most common form of dementia in the elderly individuals. Characteristics of AD consist of accumulation of $\beta$-amyloid $(A \beta)$ plaques and neurofibrillary tangles of hyperphosphorylated tau proteins (Querfurth and LaFerla, 2010). Another neuropathologic feature of $\mathrm{AD}$ is the selective degeneration of cholinergic neurons in the basal forebrain, which is associated with the cognitive decline in $\mathrm{AD}$ (reviewed in Auld et al., 2002).

The most abundant nicotinic acetylcholine receptors (nAChRs) in the brain, $\alpha 7$ and $\alpha 4 \beta 2$, are involved in cognitive performance, such as attention and memory function, as well as synaptic

\footnotetext{
* Corresponding author at: Department of Drug Design and Pharmacology, Faculty of Health and Medical Sciences, University of Copenhagen, Universitetsparken 2, DK-2100 Copenhagen, Denmark. Tel.: +4535331717.

E-mail address: morten.s.thomsen@sund.ku.dk (M.S. Thomsen).
}

plasticity (reviewed in Sarter et al., 2009; Thomsen et al., 2010). Accordingly, they have been widely investigated for their involvement in the pathology of AD. Genetic analyses have demonstrated associations between single-nucleotide polymorphisms in the $\alpha 7$ nAChR gene and AD (Carson et al., 2008b) as well as the delusional symptoms in AD (Carson et al., 2008a). Single-nucleotide polymorphisms in the genes of $\alpha 4$ (Dorszewska et al., 2005; Kawamata and Shimohama, 2002) and $\beta 2$ nAChR subunits (Cook et al., 2004; Laumet et al., 2010) have also shown to be associated with AD. Recent studies agree that $\alpha 4 \beta 2 \mathrm{nAChR}$ levels are decreased in AD. Thus, reduced $\left[{ }^{3} \mathrm{H}\right]$-nicotine binding was observed postmortem in frontal cortex of AD patients (Marutle et al., 2013), and binding of the $\alpha 4 \beta 2 \mathrm{nAChR}$ radioligand $\left[{ }^{18} \mathrm{~F}\right]-2 \mathrm{FA}-85380$, by the use of PET, was decreased in several brain regions of AD patients and demonstrated significant correlations with both $A \beta$ levels in the medial prefrontal cortex and cognitive performance of the AD patients (Okada et al., 2013). In contrast, there is currently no consensus on whether $\alpha 7$ $\mathrm{nAChR}$ levels in the brain are changed in $\mathrm{AD}$, because binding 
studies have reported either downregulation or no change (Court et al., 2001; Davies and Feisullin, 1981; Hellstrom-Lindahl et al., 1999; Marutle et al., 2013).

$\mathrm{A} \beta_{1-42}$ has been shown to bind both $\alpha 7$ and $\alpha 4 \beta 2$ nAChRs, the former with picomolar affinity, whereas its affinity for $\alpha 4 \beta 2$ was 5000 times lower (Wang et al., 2000). Furthermore, $A \beta_{1-42}$ is able to modulate the function of both $\alpha 7$ and $\alpha 4 \beta 2$ nAChRs with dosedependent effects (reviewed in Buckingham et al., 2009; Jurgensen and Ferreira, 2010).

In addition to $A \beta_{1-42}$, several members of Ly-6/neurotoxins (Lynx) protein superfamily have been shown to modulate the function of nAChRs (reviewed in Miwa et al., 2011; Thomsen and Mikkelsen, 2012). Therefore, alterations in $\alpha 7$ and $\alpha 4 \beta 2 \mathrm{nAChRs}$ may be secondary to changes in Lynx protein levels.

The Lynx superfamily has structural similarities to snake venom toxins such as $\alpha$-bungarotoxin and are characterized by a "threefingered" loop motif (Tsetlin, 1999). The Lynx proteins Lynx1 and Lynx2 have been shown to form stable complexes with and negatively regulate both $\alpha 7$ and $\alpha 4 \beta 2$ nAChRs (Ibanez-Tallon et al., 2002; Miwa et al., 2006; Tekinay et al., 2009). In addition, mice with genetic deletions of Lynx1 or Lynx2 displayed increased associative learning and elevated anxiety-like behavior, respectively (Miwa et al., 2006; Tekinay et al., 2009). Moreover, it was recently shown that Lynx1 through a nAChR-dependent action had a crucial role in the loss of synaptic plasticity observed in adult visual cortex (Morishita et al., 2010). Furthermore, transgenic overexpression of the Lynx protein Lypd6 in mice resulted in increased pre-pulse inhibition indicating possible involvement in attention (Darvas et al., 2009). Thus, Lynx proteins are suggested to be involved in cognitive function.

Prostate stem cell antigen (PSCA), another Lynx protein, was found to suppress nicotine-induced $\mathrm{Ca}^{2+}$ influx via activation of $\alpha 7$ nAChRs, when retrovirally expressed in dissociated avian ciliary ganglion neurons (Hruska et al., 2009). In contrast, nicotineinduced $\mathrm{Ca}^{2+}$ currents were enhanced in dissociated murine trigeminal ganglia neurons from transgenic mice overexpressing Lypd6, suggesting that Lypd6 is a positive modulator of nAChR function (Darvas et al., 2009).

Because nAChRs and Lynx proteins can bind directly to each other to affect cognitive function and synaptic plasticity, it is pertinent to examine the involvement of Lynx proteins in AD. The purpose of this study was to (1) investigate PSCA and Lypd6 in the human brain in relation to expression and complex formations with nAChR subtypes; (2) examine the ability of PSCA to modulate a nicotine-mediated response in PC12 cells; and (3) reveal whether the levels of the two Lynx proteins were changed in $A D$ in both human $\mathrm{AD}$ patients and transgenic $\mathrm{AD}$ mouse models.

\section{Methods}

\subsection{Human tissue}

Temporal cortical tissue was obtained from anterior temporal lobectomies in two patients ( 1 female, aged 30 years and 1 male, aged 57 years) with medically intractable temporal lobe epilepsy with hippocampal onset. Written informed consent was obtained from both patients before surgery. The study was approved by the Ethical Committee in the Capital Region of Denmark (H-2-2011104) and performed in accordance with the Declaration of Helsinki. The tissue was dissected and immediately frozen on dry ice and stored at $-80^{\circ} \mathrm{C}$ until use. The neuropathologic examinations of the neocortex from both patients were normal.

Postmortem brain tissue from medial frontal gyrus of $7 \mathrm{AD}$ subjects and 8 nondemented (non-AD) control subjects (see Table 1) were obtained from the Netherland's Brain Bank, Amsterdam, the Netherlands. Autopsies were performed on donors from
Table 1

Clinicopathologic data of the human brain material

\begin{tabular}{llllcl}
\hline Diagnosis & Age & Gender & pH & PMD (h:min) & Braak stage \\
\hline Nondemented control & 60 & $\mathrm{~F}$ & 6.27 & $06: 50$ & 1 \\
Nondemented control & 60 & $\mathrm{~F}$ & 6.80 & $07: 30$ & 1 \\
Nondemented control & 62 & $\mathrm{M}$ & 6.36 & $07: 20$ & 1 \\
Nondemented control & 78 & $\mathrm{M}$ & 6.52 & $<17: 40$ & 1 \\
Nondemented control & 87 & $\mathrm{M}$ & 7.11 & $08: 00$ & 1 \\
Nondemented control & 87 & $\mathrm{~F}$ & 6.91 & $08: 00$ & 2 \\
Nondemented control & 97 & $\mathrm{~F}$ & - & $10: 00$ & 2 \\
Nondemented control & 90 & $\mathrm{~F}$ & 6.54 & $06: 10$ & 3 \\
Alzheimer's disease & 67 & $\mathrm{~F}$ & 6.73 & $03: 30$ & 5 \\
Alzheimer's disease & 58 & $\mathrm{M}$ & 6.29 & $05: 15$ & 6 \\
Alzheimer's disease & 58 & $\mathrm{M}$ & 6.42 & $06: 25$ & 6 \\
Alzheimer's disease & 59 & $\mathrm{M}$ & 6.26 & $05: 05$ & 6 \\
Alzheimer's disease & 62 & $\mathrm{M}$ & 6.31 & $04: 15$ & 6 \\
Alzheimer's disease & 62 & $\mathrm{~F}$ & 6.53 & $04: 25$ & 6 \\
Alzheimer's disease & 62 & $\mathrm{~F}$ & 6.06 & $04: 45$ & 6 \\
\hline
\end{tabular}

Key: F, female; M, male; PMD, postmortem delay.

whom written informed consent had been obtained either from the donor or direct next of kin. All AD subjects were confirmed by standard clinical (Dubois et al., 2007; McKhann et al., 1984) and neuropathologic (Braak and Braak, 1991, 1995) diagnosis criteria.

\subsection{Animals}

Triple transgenic mice $(3 \times \mathrm{Tg}-\mathrm{AD})$, expressing mutant human transgenes (human amyloid precursor protein [APP] 695 with the Swedish double mutation K670N/M671L [hAPPSwe], tau P301L) mutation, and the presenilin-1 mutant M146V knock-in construct (Oddo et al., 2003), were studied in two different age groups: 6month-old mice $(\mathrm{n}=8)$ and 19 - to 21 -month-old mice $(\mathrm{n}=8)$ with age-matched wild-type (WT) mice (Sv129/B6; $n=7-8$ ) as controls. The mice were bred at the Medizinisch-Experimentelles Zentrum at Leipzig University. At the day of experiment, the mice were decapitated, frontal cortex and hippocampus dissected, and the tissue was immediately frozen on dry ice and stored at $-80^{\circ} \mathrm{C}$ until use.

Twelve male $\operatorname{Tg} 2576$ mice expressing the hAPPSwe mutations (Hsiao et al., 1996) and their WT littermates $(n=15)$ bred on an inbred 12956 background were obtained from Taconic (Ry, Denmark). At the age of 9 months, in an unrelated set of experiments, the mice received bilateral intracerebroventricular phosphate-buffered saline (PBS) injections (Laursen et al., 2014) followed by electrophysiological testing. Mice were euthanized at the age of 15 months, and one hemisphere was dissected, snap frozen, and kept at $-80{ }^{\circ} \mathrm{C}$ until further analysis. Frontal cortex was later separated from the frozen sample and used for Western blot analyses as described in the following.

Experiments with $3 \times \mathrm{Tg}-\mathrm{AD}$ were approved by the Animal Care and Use Committee of the University of Leipzig and local authorities (Regierungspräsidium Leipzig; T40/13) and conformed to the European Communities Council Directive (86/609/EEC). Experiments with Tg2576 mice were approved by the Danish National Committee for Ethics in Animal Experimentation.

\subsection{Tissue fractionation}

To fraction tissue into membrane and soluble fractions, human temporal cortical tissue from neurosurgery $(150-170 \mathrm{mg}, \mathrm{n}=2)$ was homogenized $2 \times 30$ seconds in Buffer1 $(0.5 \mathrm{M} \mathrm{NaCl}, 50 \mathrm{mM}$ Tris- $\mathrm{HCl}, 10 \mathrm{mM} \mathrm{MgCl}, 2 \mathrm{mM}$ ethylenediaminetetraacetic acid (EDTA), $10 \mu \mathrm{L} / \mathrm{mL}$ protease inhibitor cocktail [Sigma-Aldrich, Brøndby, Denmark], pH 7.3) using a PT1200C polytron blender (Kinematica, Luzern, Switzerland) and centrifuged for 30 minutes 
at $126,000 \mathrm{~g}$ at $20{ }^{\circ} \mathrm{C}-22{ }^{\circ} \mathrm{C}$ using an air-driven ultracentrifuge (Airfuge, Copenhagen, Denmark). The supernatant containing the soluble fraction was transferred to a new tube, and the pellet containing the membrane fraction was washed twice in Buffer1, resuspended by blending $2 \times 30$ seconds in Buffer2 ( $4 \mathrm{M}$ urea, $50 \mathrm{mM}$ Tris $-\mathrm{HCl}, 1 \% \mathrm{SDS}, 10 \mu \mathrm{L} / \mathrm{mL}$ protease inhibitor cocktail, $\mathrm{pH}$ 7.3 ), and sonicated $3 \times 5$ seconds on ice.

\subsection{PSCA affinity purification}

Recombinant human GST-tagged PSCA produced in Escherichia coli (purchased from MyBioSource Inc, San Diego, CA) and dissolved to $0.7 \mathrm{mg} / \mathrm{mL}$ in PBS, pH 7.4 was coupled to PureProteome NHS Flexibind magnetic beads (Millipore, Billerica, MA) in a ratio of $1: 1.25(\mathrm{vol} / \mathrm{vol})$. In brief, beads were washed once in ice-cold $1 \mathrm{mM}$ $\mathrm{HCl}$ before addition of the PSCA solution. Subsequently, beads were incubated overnight at $4{ }^{\circ} \mathrm{C}$ in a rotator (15 rpm). Unbound PSCA was removed, and the beads were resuspended and washed four times in Quench buffer ( $100 \mathrm{mM}$ Tris- $\mathrm{HCl}, 150 \mathrm{mM} \mathrm{NaCl}, \mathrm{pH} 8.0$ ) followed by incubation for 1 hour at room temperature. A batch of beads without PSCA in the PBS was processed in parallel as a negative control. The beads were incubated in $0.1 \%$ bovine serum albumin in PBS, pH 7.4, for 1 hour at $4{ }^{\circ} \mathrm{C}$ before use.

The tissue was lysed in $1 \mathrm{~mL}$ lysis buffer ( $50 \mathrm{mM}$ Tris, $50 \mathrm{mM} \mathrm{NaCl}$, 5 mM EDTA, 5 mM EGTA, $10 \mu \mathrm{L} / \mathrm{mL}$ protease inhibitor cocktail [SigmaAldrich, pH 7.5]) using the PT1200C polytron blender for 20 seconds. The lysate was centrifuged for 30 minutes at $160,000 \mathrm{~g}$ at $20^{\circ} \mathrm{C}-22^{\circ} \mathrm{C}$ using the air-driven ultracentrifuge and the supernatant discarded. The pellet was resuspended in $1 \mathrm{~mL}$ lysis buffer containing $2 \%$ Triton $\mathrm{X}-100$ by blending for 20 seconds and incubated for 2 hours at $4{ }^{\circ} \mathrm{C}$ on a rotor $(15 \mathrm{rpm})$. Thereafter, the sample was centrifuged as mentioned previously, and the resulting supernatant (input) was used for affinity purification. Total protein content was determined using the Pierce $660 \mathrm{~nm}$ Protein Assay (Thermo Scientific, Rockford, IL), and $1000 \mu \mathrm{g}$ protein was incubated with $50 \mu \mathrm{L}$ magnetic beads in a total volume of $1500 \mu \mathrm{L}$ lysis buffer for $18-22$ hours at $4{ }^{\circ} \mathrm{C}$ in a rotator (15 rpm). A sample of the homogenate after affinity purification was taken (output). Subsequently, the beads were washed twice in $1 \mathrm{M} \mathrm{NaCl}$, $8 \mathrm{mM} \mathrm{Na}_{2} \mathrm{HPO}_{4}, 2 \mathrm{mM} \mathrm{NaH} \mathrm{PO}_{4}, 0.5 \%$ Triton X-100, pH 7.5 and three times in an identical buffer, where $1 \mathrm{M} \mathrm{NaCl}$ was substituted with $0.1 \mathrm{M} \mathrm{NaCl}$, and thereafter, the samples were immediately processed for Western blotting.

\subsection{ERK phosphorylation and $\beta 2 n A C h R$ expression in PC12 cells}

PC12 cells were maintained in $75 \mathrm{~cm}^{2}$ flasks coated with $5 \mu \mathrm{g} / \mathrm{mL}$ poly-L-lysine (Sigma-Aldrich), in Dulbecco modified Eagle medium (DMEM, Gibco Life Technologies, NY) supplemented with $10 \%$ heatinactivated horse serum, $5 \%$ fetal bovine serum, $25 \mathrm{U} / \mathrm{mL}$ penicillin, $25 \mu \mathrm{g} / \mathrm{mL}$ streptomycin, $1 \mathrm{mM}$ sodium pyruvate, and $2 \mathrm{mM}$ glutamine (complete culture medium) at $37^{\circ} \mathrm{C}$ in a humidified incubator with $5 \% \mathrm{CO}_{2}$. Cells were subcultured every 3-4 days by detachment with $0.25 \%$ trypsin in EDTA solution (Gibco Life Technologies) and reseeded at $15 \%$ confluence.

For the extracellular-signal regulated kinase (ERK) phosphorylation assay, cells were seeded in 24 -well plates at $12 \times 10^{4}$ cells/ $\mathrm{cm}^{2}$, in low serum medium ( $1 \%$ heat-inactivated horse serum, $0.5 \%$ fetal bovine serum) 24 hours before the experiments, which started by incubating cells for 10 minutes with recombinant human PSCA protein (MyBiosource) in the concentrations (0.1, 1, and $10 \mu \mathrm{M}$ ) diluted in DMEM, followed by stimulation with $25 \mu \mathrm{M}$ nicotine (Sigma-Aldrich) for 5 minutes. For the $\beta 2$ nAChR expression assay, PC12 cells were seeded in 96-well plates at $12 \times 10^{4}$ cells $/ \mathrm{cm}^{2}$ on the day of the experiment in complete culture medium. Subsequently, cells were stimulated for 24 hours with recombinant human PSCA protein (MyBiosource) in the concentrations (0.1, 1, and $10 \mu \mathrm{M}$ ) diluted in DMEM. Thereafter, cells were immediately lysed in $100 \mu \mathrm{L}$ and $50 \mu \mathrm{L}$, respectively, ice-cold lysis buffer/well (100 mM NaCl, 25 mM EDTA, $10 \mathrm{mM}$ Tris, 4 mM Na $3 V_{4}, 1 \mathrm{mM} \mathrm{NaF}$ and $1 \%[\mathrm{vol} / \mathrm{vol}]$ Triton X-100,1\% [vol/vol] NP-40, $1 \mu \mathrm{L} / \mathrm{mL}$ protease inhibitor cocktail [Sigma-Aldrich], $\mathrm{pH}$ 7.4). To ensure complete lysis, lysates were then placed in $-80{ }^{\circ} \mathrm{C}$ for 15 minutes, thawed, and sonicated for 5 seconds on ice. Lysates were stored at $-80{ }^{\circ} \mathrm{C}$ until they were processed for Western blotting.

\subsection{Small interfering RNA transfection and real-time quantitative} reverse transcription polymerase chain reaction

FlexiTube small interfering RNA (siRNA) (Qiagen, Limburg, the Netherlands) against PSCA (TACAATCATCCTGTAATAAAT) and a scrumbled negative control were diluted in DMEM (Gibco Life Technologies) to a final concentration of $50 \mathrm{nM}$. The transfection reagent Lipofectamine 2000 (Life Technologies, Carlsbad, CA) was diluted in opti-MEM (Life Technologies) and incubated for 5 minutes at room temperature according to the manufacturer's instructions. siRNAs were mixed with the transfection reagent and incubated further for 15 minutes at room temperature to allow the formation of transfection complexes. Subsequently, $100 \mu \mathrm{L}$ of transfection complexes were added into each well of a 24-well plate, and PC12 cells were seeded at $24 \times 10^{4} \mathrm{cells} / \mathrm{cm}^{2}$ in complete culture medium without antibiotics. Cells were incubated at $37{ }^{\circ} \mathrm{C}$ in a humidified incubator with $5 \% \mathrm{CO}_{2}$. After 48 hours, the medium was removed, the plate was placed on ice, and RNA was immediately extracted using the RNeasy Mini Kit (Qiagen) according to the manufacturer's instructions.

RNA samples were dissolved in RNase-free water, and RNA content was quantified using a Nanodrop ND-1000 Spectrophotometer (Nanodrop Technologies, Wilmington, DE). Samples were diluted with RNase-free water to equal RNA concentrations and reverse transcribed into single-stranded complementary DNA (cDNA) with the ImProm-II Reverse Transcription System (Promega, Madison, WI) according to the manufacturer's directions using $0.5 \mathrm{~g} /$ reaction oligo $(\mathrm{dT})_{15}$ primers, $6 \mathrm{mM} \mathrm{MgCl} 2$, and 20 units of RNase inhibitor. Real-time quantitative reverse transcription polymerase reactions (RT-qPCR) were performed in a total volume of $20 \mu \mathrm{L}$, containing $1 \mu \mathrm{L}$ sample cDNA, $1 \times$ Brilliant II SYBR Green qPCR Master Mix (Stratagene, La Jolla, CA), and 15 pmol each of the forward and reverse primers (DNA Technology, Aarhus, Denmark). RTqPCR was performed on a Light Cycler 480 Real-Time PCR System (Roche, Indianapolis, IN) with a 10 -minute preincubation at $94{ }^{\circ} \mathrm{C}$ followed by 40 cycles of 30 seconds at $94^{\circ} \mathrm{C}, 45$ seconds at $60{ }^{\circ} \mathrm{C}$, and 90 seconds at $72{ }^{\circ} \mathrm{C}$. Primer pairs were validated by using serially diluted cDNA to establish a standard curve and by confirming the existence of a single product on a gel at the correct molecular weight. Quantification of messenger RNA (mRNA) expression was performed according to the comparative $C_{T}$ method as described by (Schmittgen and Livak, 2008). For each sample, the amount of target mRNA was normalized to the amount of GAPDH.

The sequence of the designed primers were as follows: PSCA, forward 5'-GCCCTACCAGTTCTGATCAG-3', reverse 5'-TCACACCCACCTAGCTTCAT3'; $\beta 2$ nAChR, forward 5'-ACGGTGTTCCTGCTGCTCATC-3', reverse 5'-CACACTCTGGTCATCATCCTC-3'; and GAPDH, forward 5'-CATCAAGAAGGTGGTGAAGCA-3', reverse 5'-CTGTTGAAGTCACAGGAGACA-3'.

\subsection{Tissue preparation for Western blotting}

Human postmortem cortical tissue was lysed in homogenization buffer (50 mM Tris, $100 \mathrm{nM} \mathrm{NaCl}, 25$ mM EDTA, 1\% [vol/vol] Triton$\mathrm{X}, 1 \%$ [vol/vol] NP-40, $1 \mu \mathrm{L} / \mathrm{mL}$ protease inhibitor cocktail [SigmaAldrich], pH 7.4). Mouse cortical tissue was lysed in lysis buffer 
(50 mM Tris- $\mathrm{HCl}, 4 \mathrm{M}$ urea, $1 \%$ [wt/vol] SDS, $1 \mu \mathrm{L} / \mathrm{mL}$ protease inhibitor cocktail [Sigma-Aldrich], pH 7.4). All lysates were briefly sonicated $2 \times 5$ seconds and centrifuged at $1000 \mathrm{~g}$ for 10 minutes at $4{ }^{\circ} \mathrm{C}$. The resultant supernatant was used for detection of proteins using Western blotting as described in the following.

\subsection{Western blotting}

Total protein content was determined using the DC Protein Assay Kit (BioRad, Hercules, CA), and the samples were diluted in loading buffer (final concentration: $60 \mathrm{mM}$ Tris, 10\% [vol/vol] glycerol, 5\% [vol/vol] mercaptoethanol, 2\% [wt/vol] SDS, 0.025\% [wt/ vol] bromophenol blue, $\mathrm{pH} 6.8$ ), incubated for 5 minutes at $95{ }^{\circ} \mathrm{C}$, and submitted to gel electrophoresis using AnykD gels (BioRad). After blotting onto polyvinylidene difluoride membranes (BioRad), the membranes were washed in Tris-buffered saline with $0.1 \%$ Tween 20 (TBS-T), and blocked in TBS containing 5\% (wt/vol) dry milk powder. Blots were incubated in primary antisera against PSCA (1:1,000, \#NB100-91938, Novus Biologicals, Cambridge, UK), Lypd6 (1:1,000, \#ARP53451_P050, Aviva Systems Biology, San Diego, CA), $\beta 2$ nAChR subunit $(1: 1,000$, kindly provided by Dr Cecilia Gotti, previously characterized in Thomsen et al., 2014), GluR2 (1:200, \#MABN71, Millipore), $\alpha 4$ nAChR subunit (1:100, sc-5591, Santa Cruz Biotechnology), $\alpha 7$ nAChR subunit (1:1000 \#ab23832, Abcam, Cambridge, UK), or actin (1:10,000, \#A5060, Sigma-Aldrich) overnight at $4{ }^{\circ} \mathrm{C}$. Subsequently, blots were washed in TBS-T $3 \times$ 10 minutes followed by 1 hour incubation at room temperature with horseradish peroxidase-conjugated secondary antibodies (1:2000, Dako, Glostrup, Denmark). After thorough washing in TBS$\mathrm{T}$, blots were visualized by enhanced chemiluminescence reagents (Western Lightning ECL Pro, Perkin Elmer, Waltham, MA) using a Chemidoc XRS system with Quantity One software (BioRad). Data were quantified by measuring mean optical densities of bands and subtracting an adjacent background measurement.

Validation of PSCA antibody (1:1,000, Novus Biologicals) was done with co-incubation with the PSCA peptide, which had been used as immunogen (1:100, \# NB100-91938PEP, Novus Biologicals). To determine the amount of endogenous PSCA in cortex, cortical samples from mouse and human cortex were loaded along with samples with known concentrations of the recombinant PSCA $(0.5$, $1,2,4,8$, and $16 \mathrm{ng})$. A standard curve was created based on the PSCA samples and used to determine the amount of PSCA in the cortical samples.

\subsection{Immunofluorescence labeling}

Age-matched $3 \times$ Tg-AD and WT mice $(n=8)$ were perfused transcardially with phosphate-buffered $4 \%$ paraformaldehyde after being euthanized with $\mathrm{CO}_{2}$. Dissected brains were immersed in fixative overnight, dehydrated, and cut with a freezing microtome resulting in free-floating, $30-\mu \mathrm{m}$-thick coronal sections. Selected sections containing the frontal cortex or the hippocampal formation were used for phospho-tau and $A \beta$-immunolabeling according to an earlier protocol with minor modifications (Härtig et al., 2014). Tissues were incubated with a mixture of biotinylated mouse-antiA $\beta_{17-24}$ (4G8; Covance, Emeryville, CA; $1: 400$ in TBS with 5\% normal donkey serum) and rabbit-anti-phospho-tau205 (Invitrogen, Karlsruhe, Germany; 1:300) overnight. Subsequently, the sections were rinsed with TBS and incubated for 1 hour in a mixture of carbocyanine 2 (Cy2)-conjugated streptavidin and Cy3-tagged donkey anti-rabbit IgG (both from Dianova, Hamburg, Germany; $20 \mu \mathrm{g} / \mathrm{mL}$ TBS containing $2 \%$ bovine serum albumin). After washing with TBS, the sections were treated with Sudan Black B for $10 \mathrm{mi}-$ nutes (Schnell et al., 1999) and mounted onto glass slides. For data illustration, images were taken from selected sections using a 510
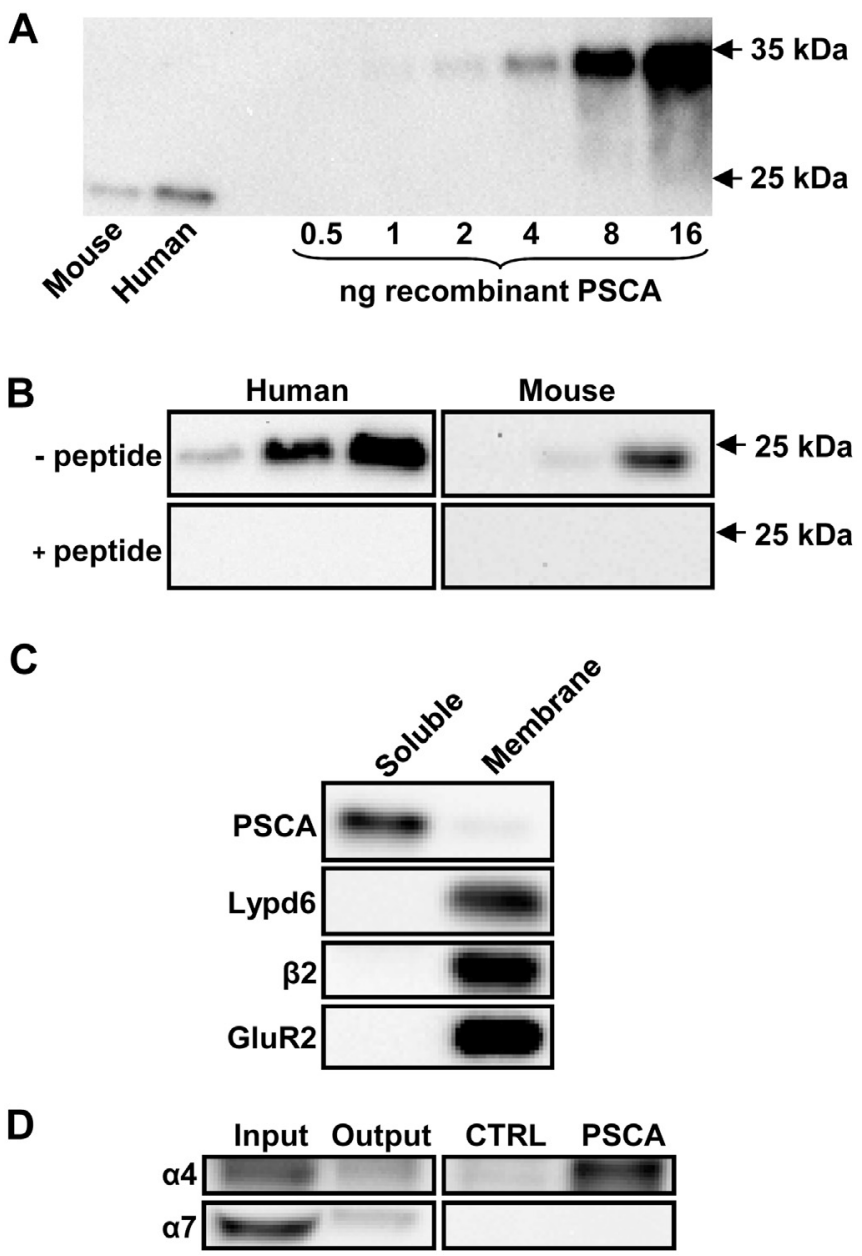

Fig. 1. Prostate stem cell antigen (PSCA) is soluble and co-purifies with the $\alpha 4 \mathrm{nAChR}$ subunit in human cortex. (A) The antiserum directed against PSCA recognizes the human recombinant GST-tagged PSCA protein (total molecular weight $34.2 \mathrm{kDa}$ ) from 1 to $16 \mathrm{ng} /$ well at the expected band size. Endogenous PSCA from mouse and human cortical tissue ( $8 \mu \mathrm{g}$ total protein/well) is detected at approximately $24 \mathrm{kDa}$, and the amount in the cortical samples was compared with the known concentrations of recombinant PSCA protein. (B) Images of Western blot showing PSCA protein levels in cortical tissue from human (protein concentration 4,8 , and $12 \mu \mathrm{g} /$ well) and mouse ( 8 , 15 , and $30 \mu \mathrm{g} /$ well) in the absence (-peptide) and the presence of PSCA peptide (+peptide). (C) Representative images of Western blots showing PSCA and Lypd6 protein levels in soluble and membrane fractions of human temporal cortical tissue. The membrane receptor proteins $\beta 2 \mathrm{nAChR}$ and GluR2 are used as control. (D) Magnetic beads covalently coupled with PSCA recombinant protein were incubated with cortical homogenates from human temporal cortex followed by detection of nAChR subunits by Western blot. Homogenates before (input) and after affinity purification (output) as well as the negative control (CTRL) were loaded.

Meta confocal laser-scanning microscope (Zeiss, Jena, Germany) and processed with CorelDraw and/or Photo-Paint version 12.0 (Corel Corp, Ottawa, Canada).

\subsection{Statistical analyses}

Data from PC12 cells were analyzed using one-way analysis of variance (ANOVA) with Dunnett multiple comparisons test. Correlation of age, postmortem delay, and $\mathrm{pH}$ with protein levels in human subjects was done using Pearson correlation analysis. Twoway ANOVA was applied to analyze effects of genotype and age in $3 \times \mathrm{Tg}$-AD mice. Unpaired multiple $t$ tests using the Holm-Sidak method was used to compare groups. The statistical calculations were performed using GraphPad Prism version 6 for Windows (GraphPad Software, San Diego, CA). Data are presented as mean \pm 
A

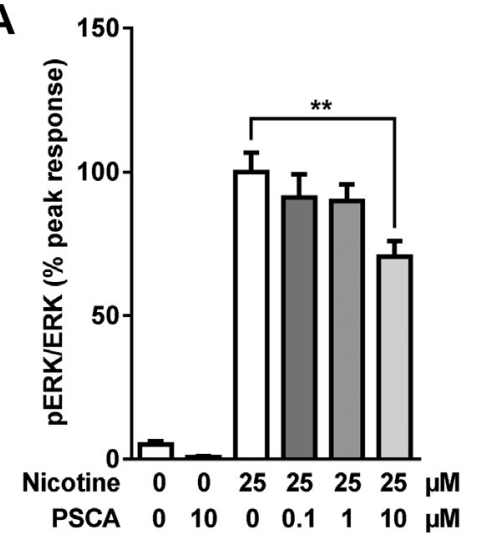

B

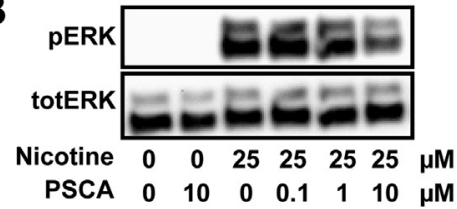

c

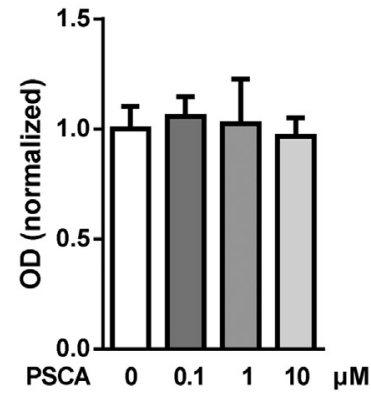

D

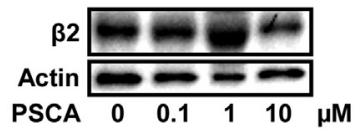

E

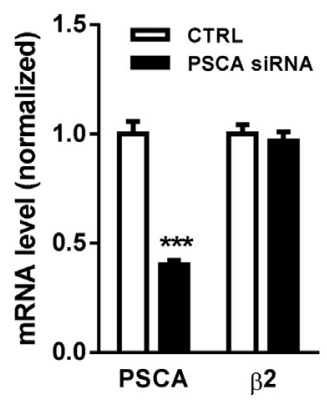

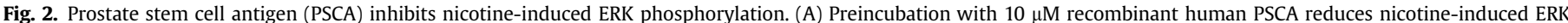

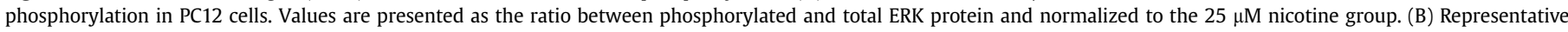

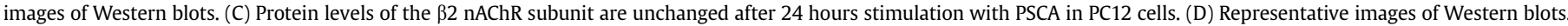

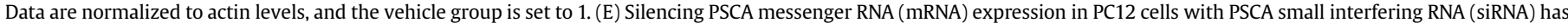

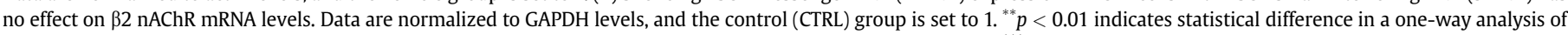

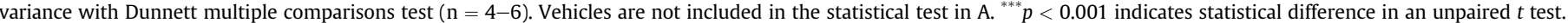

standard error of the mean, and $p<0.05$ was considered as statistically significant.

\section{Results}

\subsection{PSCA is a soluble protein that binds to $\alpha 4 n A C h R$ subunits in the human cortex}

The PSCA antiserum recognized recombinant human PSCA protein in the concentration range of $1-16 \mathrm{ng} /$ well at molecular weight band of approximately $34 \mathrm{kDa}$ (Fig. 1A). Recombinant PSCA protein consisted of 75 amino acids (immunogen sequence positions 21-95) with a calculated molecular weight of $8.2 \mathrm{kDa}$. However, this protein was GST-tagged (approximately $26 \mathrm{kDa}$ ) resulting in a total molecular weight of approximately $34 \mathrm{kDa}$, which correlated with the molecular weight of the identified protein (Fig. 1A). A band at a molecular weight of approximately 24 kDa was detected by Western blotting in extracts from both human frontal cortex (Fig. 1A), human temporal cortex (Fig. 1B), and mouse frontal cortex (Fig. 1A and B). To estimate protein levels of PSCA in cortical tissue, the intensity of PSCA staining in cortical samples was compared with that of recombinant PSCA with known concentrations (Fig. 1A). Based on the standard curve, cortical tissue was estimated to contain 0.3 and $0.5 \mathrm{ng} / \mu \mathrm{g}$ total protein for mouse and human cortex, respectively. Co-incubation of the diluted PSCA antiserum with the immunogen peptide prevented detection of bands in both human and mouse cortical extracts (Fig. 1B).

Human temporal cortical tissue was fractionated into soluble and membrane fractions by ultracentrifugation, and the resulting fractions were subjected to Western blotting (Fig. 1C). PSCA was detectable only in the soluble fraction. On the contrary, Lypd6 was detected only in the membrane fraction. To validate the fractionation method, we show that the two receptor units, $\beta 2 \mathrm{nAChR}$ and GluR2, were only present in the membrane fraction (Fig. 1C).

Affinity purification from human temporal cortical homogenates using magnetic beads coupled to recombinant human PSCA demonstrated that PSCA was able to isolate the $\alpha 4 \mathrm{nAChR}$ subunit (Fig. 1D). Affinity purification using uncoupled beads yielded no isolation of $\alpha 4$ protein. By contrast, PSCA did not isolate the $\alpha 7$ nAChR subunit.

\subsection{PSCA regulates nicotine-induced ERK phosphorylation in PC12 cells}

Nicotine induces phosphorylation of the MAP kinase ERK in PC12 cells (Fig. 2A). Recombinant human PSCA at $10 \mu \mathrm{M}$ significantly inhibited nicotine-induced ERK phosphorylation by approximately $30 \%$ in PC12 cells ( $p<0.01$ ), whereas 0.1 and $1 \mu \mathrm{M}$ had no significant effects. PSCA alone did not affect basal levels of ERK phosphorylation.

Stimulation of PC12 cells with PSCA $(0.1,1$, and $10 \mu \mathrm{M})$ for 24 hours did not alter $\beta 2$ protein levels (Fig. 2 C). In addition, $\beta 2$ mRNA levels in PC12 cells were unchanged, when silencing PSCA levels using PSCA siRNA (Fig. 2E). The expression of PSCA was reduced to approximately $40 \%$ by PSCA siRNA, when compared with the expression in the presence of the negative control siRNA.

\subsection{PSCA levels are increased in frontal cortex of $A D$ patients}

PSCA, Lypd6, and $\beta 2$ protein levels were determined in human postmortem cortical tissue from medial frontal gyrus using Western blotting (Fig. 3). The levels of PSCA were increased by approximately $70 \%$ in $\mathrm{AD}$ postmortem tissue compared with nondemented (non-AD) control subjects $(1.71 \pm 0.16, p=0.0025)$, whereas Lypd6 levels were unchanged $(0.99 \pm 0.12, p=0.97)$. Levels of the $\beta 2$ $\mathrm{nAChR}$ subunit were significantly decreased in AD patients $(0.66 \pm$ $0.06, p=0.014$ ).

Although AD subjects were noted to be slightly younger and have slightly shorter postmortem delay than the non-AD control subjects (see Table 1), we found no correlation between any of these parameters or $\mathrm{pH}$ with protein levels of PSCA, Lypd6, and $\beta 2 \mathrm{nAChR}$ within the non-AD or AD groups. 


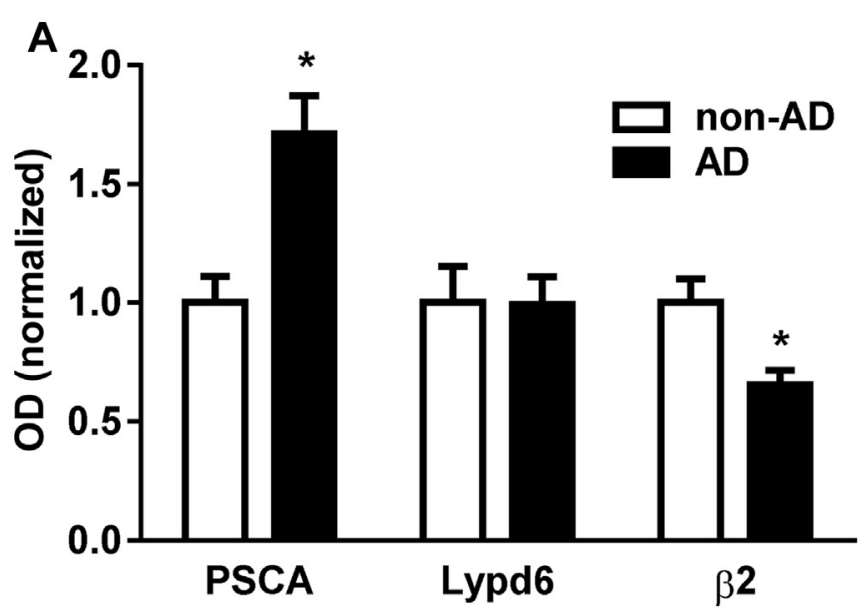

B

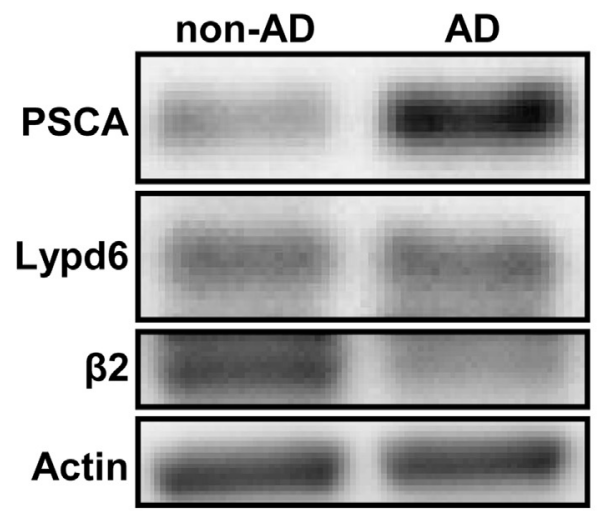

Fig. 3. Prostate stem cell antigen (PSCA) protein levels are increased in medial frontal gyrus in Alzheimer's disease (AD). (A) Quantification of PSCA and Lypd6 protein levels as well as the $\beta 2 \mathrm{nAChR}$ subunit in homogenized postmortem tissue of medial frontal gyrus from $A D$ patients and nondemented control subjects (non-AD). (B) Representative Western blot images of protein levels of non- $A D$ and $A D$ patients. Data are normalized to actin levels, and the non-AD control group is set to $1 .{ }^{*} p<0.05$ indicates statistical difference from non-AD control subjects in multiple $t$ tests with Holm-Sidak multiple comparison test $(n=7-8)$.

\subsection{PSCA levels are increased in frontal cortex of $3 \times T g-A D$ mice}

Protein levels of PSCA, Lypd6, and the $\beta 2 \mathrm{nAChR}$ subunit were determined in frontal cortex and hippocampus from 6 to 19- to 21month-old $3 \times$ Tg-AD mice and age-matched WT controls using Western blotting (Fig. 4). In frontal cortex using two-way ANOVA with age and genotype as independent variables, there was no interaction of the variables, but a significant main effect of genotype on PSCA and $\beta 2 \mathrm{nAChR}$ levels in $3 \times \mathrm{Tg}-\mathrm{AD}$ mice in the two age groups $(p<0.01$ and $p<0.05$, respectively) compared with age-matched WT mice (Fig. 4A), whereas there was no significant main effect of age. Subsequent unpaired $t$ tests revealed that the effect of genotype was driven primarily by the 6 -month group, where $3 \times \mathrm{Tg}$-AD mice had significantly enhanced PSCA $(1.46 \pm 0.17, p=0.038)$ and significant lower $\beta 2$ nAChR levels $(0.79 \pm 0.04, p<0.01)$ compared with age-matched WT animals. PSCA and $\beta 2$ nAChR levels in 19- to 21 -month-old $3 \times \mathrm{Tg}$-AD mice were not significantly altered in unpaired $t$ tests ( $p=0.10$ and $p=0.23$, respectively). In the hippocampus (Fig. 4A), there were no significant main effects on PSCA and $\beta 2 \mathrm{nAChR}$ levels of genotype ( $p=0.05$ and $p=0.06$, respectively) or age ( $p=0.19$ and $p=0.35$, respectively) in a two-way ANOVA. A twoway ANOVA did not reveal any main effect of genotype or age in Lypd6 levels in frontal cortex ( $p=0.98$ and $p=0.80$, respectively) or hippocampus ( $p=0.42$ and $p=0.94$, respectively).
Immunofluorescence labeling was applied to sections of frontal cortex and hippocampus in 21-month-old $3 \times \mathrm{Tg}$-AD mice (Fig. 4C). Frontal cortex displayed extracellular amyloid plaques as well as intracellular deposits intermingled with phospho-tauimmunoreactivity. In hippocampus, tau hyperphosphorylation was present, and $\beta$-amyloidosis was more pronounced than in frontal cortex (Fig. 4C). In 6-month-old $3 \times \mathrm{Tg}-\mathrm{AD}$ mice, weak intracellular $A \beta$ staining was displayed in both frontal cortex and hippocampus. The staining of tissues comprising frontal cortex and the hippocampus in age-matched WT mice revealed neither $A \beta$ immunoreactive senile plaques nor hyperphosphorylated tau (see Supplementary Fig. 1).

\subsection{PSCA levels are unchanged in frontal cortex of $\operatorname{Tg} 2576$ mice}

In frontal cortex of $\mathrm{Tg} 2576$ mice, there were no significant changes in the levels of PSCA, Lypd6, and $\beta 2$ nAChR subunit (Fig. 5) compared with WT animals in unpaired $t$ tests.

\section{Discussion}

Here, we show that the Lynx proteins PSCA and Lypd6 are present in the human brain and that PSCA forms stable complexes with the $\alpha 4 \mathrm{nAChR}$ subunit in the human temporal cortex and is able to decrease nicotine-induced ERK phosphorylation in PC12 cells. We further demonstrate that PSCA is increased in the frontal cortex of AD patients as well as in $3 \times \mathrm{Tg}-\mathrm{AD}$ mice. Because $3 \times \mathrm{Tg}-\mathrm{AD}$ display both age-dependent $\beta$-amyloidosis and tauopathy, this finding suggests that increased levels of PSCA are linked to the pathophysiology of AD.

PSCA was first identified as a protein that was upregulated in prostate cancer (Reiter et al., 1998). PSCA mRNA has previously been demonstrated in the central nervous system of adult mouse and chicken embryos (Hruska et al., 2009), and Lypd6 mRNA has been found in human and mouse brain tissue (Darvas et al., 2009; Zhang et al., 2010). We demonstrate that PSCA and Lypd6 proteins are present in the human cortex. Because these Lynx proteins have been associated with regulation of $\mathrm{nAChR}$ function in dissociated neurons from chicken and mouse (Darvas et al., 2009; Hruska et al., 2009), it is pertinent to study their function in the healthy and diseased human brain.

Lynx proteins can exist as either glycosylphosphatidylinositol (GPI)-anchored membrane proteins or soluble proteins (Adermann et al., 1999; Bamezai, 2004). PSCA mRNA contains a GPI anchor signaling site (Hruska et al., 2009; Reiter et al., 1998), and PSCA protein is both secreted and cell-associated in PSCA-transfected 293T cells (Reiter et al., 1998). We detected native PSCA in the human brain exclusively as a soluble protein. Lypd6 was found to be membrane-bound in the human cortex, which is in line with previous data on rat cortical tissue (Thomsen et al., 2013). Some GPIanchored proteins have been shown to have both membrane bound and secreted forms, for example, CD59, another member of the Lynx superfamily (Fritz and Lowe, 1996; Meri et al., 1996). Soluble Lynx can diffuse to sites not available to the membranebound GPI-anchored proteins. This may have an impact on how Lynx proteins exert their function, for example, it was reported that transgenic mice expressing secreted or full-length Lynx1, respectively, show different effects in terms of motor learning (Miwa and Walz, 2012).

We demonstrate that PSCA and the $\alpha 4$ nAChR subunit form stable complexes in human cortex using affinity purification with recombinant PSCA. We have recently shown that Lypd6 binds to multiple nAChR subtypes in the human cortex (Thomsen et al., 2013), and Lynx1 and Lynx2 have been shown to coimmunoprecipitate with $\alpha 7$ and $\alpha 4 \beta 2$ nAChR subunits in 

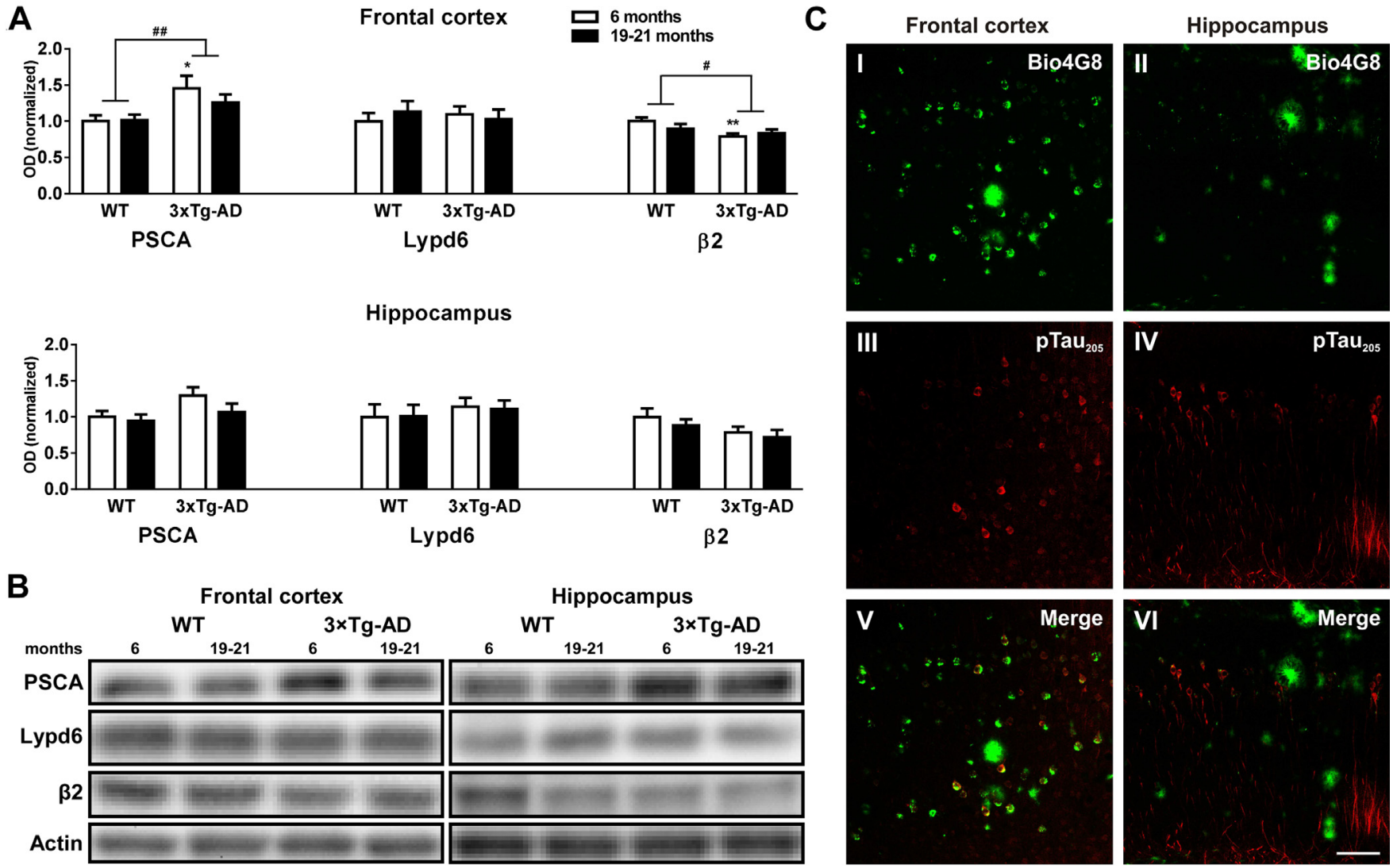

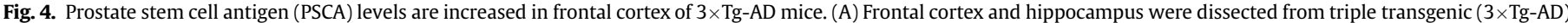

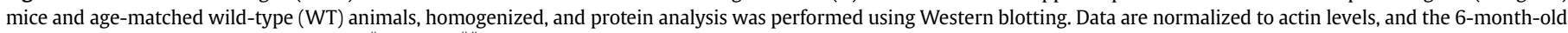

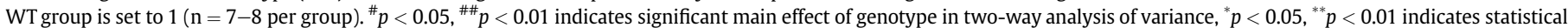

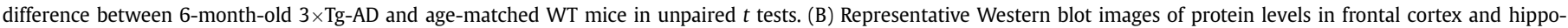

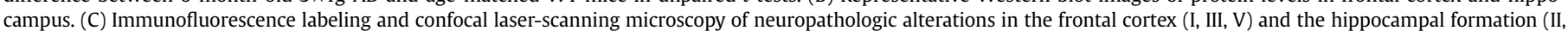

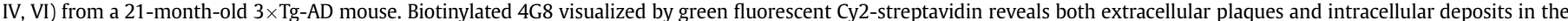

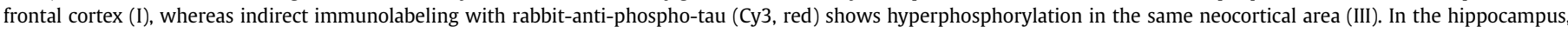

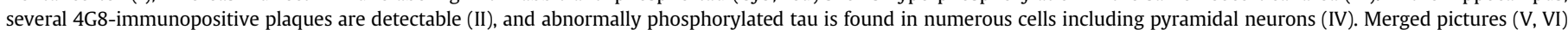

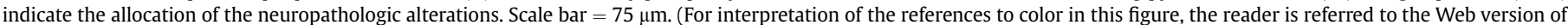
this article.)

heterologous expression systems (Ibanez-Tallon et al., 2002; Tekinay et al., 2009). These studies suggest that there may be an entire subfamily of Lynx proteins that bind to nAChRs in the brain.

It has previously been suggested that PSCA may be a negative modulator of $\alpha 7 \mathrm{nAChRs}$ in chicken cililiary ganglion neurons (Hruska et al., 2009). We did not detect co-purification of the $\alpha 7$ nAChR subunit using PSCA affinity purification on human cortical extracts. Possibly, the binding between PSCA and the $\alpha 7 \mathrm{nAChR}$ subunit is not strong enough to be detected in our assay. Alternatively, the binding of PSCA to nAChR subunits differs between species, as it has been shown for Lynx1. Human Lynx1 competes with binding of the $\alpha 7 \mathrm{nAChR}$ antagonist $\alpha$-bungarotoxin to acetylcholine-binding proteins and Torpedo nAChRs with an $\mathrm{IC}_{50}$ of approximately $10 \mu \mathrm{M}$, suggesting that it binds to the orthosteric site, whereas it does not compete with $\alpha$-bungarotoxin binding to human $\alpha 7 \mathrm{nAChRs}$ or with $\left[{ }^{3} \mathrm{H}\right]$-epibatidine binding to human $\alpha 4 \beta 2$ nAChRs (Lyukmanova et al., 2011).

To investigate the potential effect of PSCA on nAChR function, we determined the effect of PSCA on nicotine-induced phosphorylation of the MAP kinase ERK. Activation of the intracellular MAPK/ERK signaling pathway by phosphorylation plays a crucial role in the formation of long-term potentiation and memory in hippocampus (Adams and Sweatt, 2002). Nicotine has been suggested to induce
ERK phosphorylation in PC12 cells through $\alpha 3 \beta 4$ (Nakayama et al., 2006) and to some extent $\alpha 7$ nAChRs (El Kouhen et al., 2009; Gubbins et al., 2010). We show that $10 \mu \mathrm{M}$ PSCA inhibits nicotineinduced ERK phosphorylation in PC12 cells with no effect on basal levels of ERK phosphorylation indicating that the inhibitory effect is unique to nAChR signaling. The concentration of PSCA corresponds to studies with Lynx1, which showed that $10 \mu \mathrm{M}$ Lynx1 was able to inhibit ACh-induced currents in Xenopus oocytes expressing human $\alpha 7, \alpha 4 \beta 2$, and $\alpha 3 \beta 2$, whereas $1 \mu \mathrm{M}$ Lynx 1 was not (Lyukmanova et al., 2011). These data suggest that PSCA could bind to $\alpha 7 \mathrm{nAChRs}$, although we were not able to detect it and possibly also to $\alpha 3 \beta 4$ nAChRs. Thus, PSCA may function as a modulator of $\mathrm{nAChR}$ function in the brain. That PSCA affects a signaling pathway known to be important for neural plasticity and memory, makes it an interesting target for future studies.

With the demonstration that PSCA and Lypd6 bind to and modulate nAChRs, it is pertinent to investigate the function of PSCA and Lypd6 in diseases, where nAChRs are dysregulated, such as AD. nAChRs are important for normal cognitive function, and some studies suggest a correlation between nAChR levels and cognitive deficits in AD (Nordberg et al., 1995; Okada et al., 2013; Perry et al., 2000). Recent studies suggest that Lynx1, Lynx2, and Lypd6 are involved in cognitive processes in rodents (Darvas et al., 2009; 


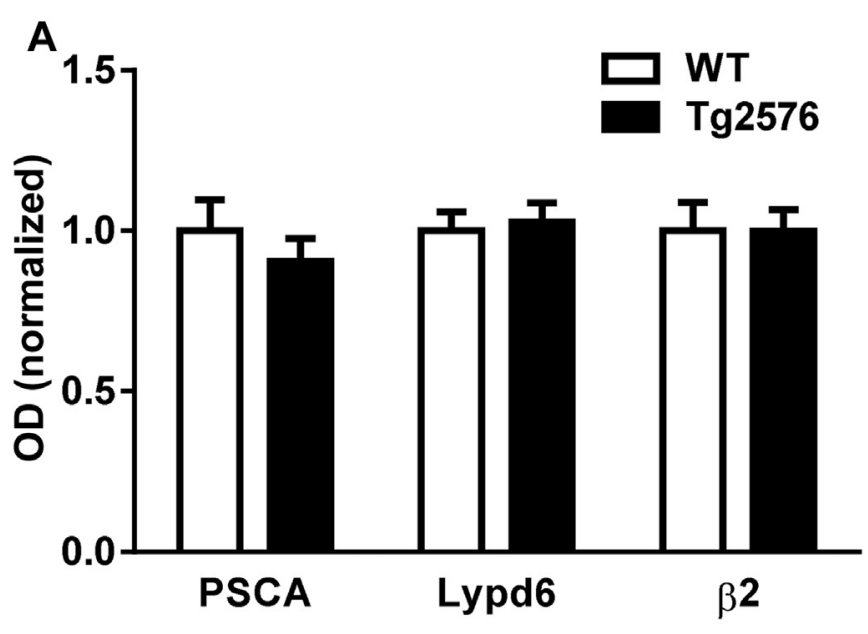

B

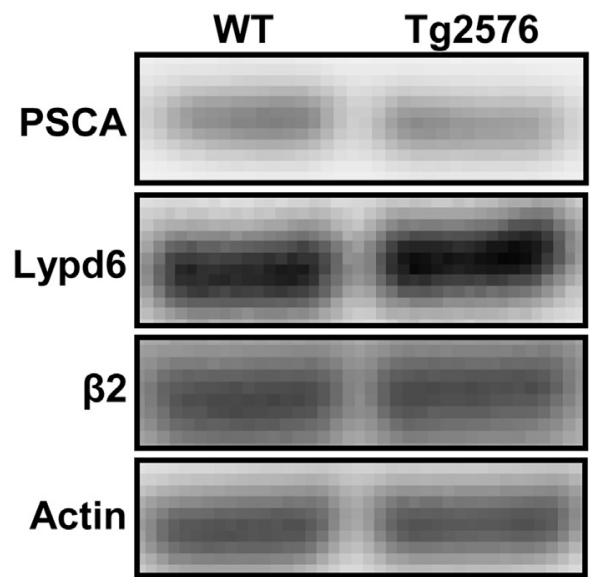

Fig. 5. No changes in prostate stem cell antigen (PSCA) levels in frontal cortex of Tg2576 mice over-expressing $\beta$-amyloid. (A) Frontal cortical extracts dissected from 15month-old male Tg2576 mice and age-matched wild-type (WT) controls were homogenized and followed by Western blotting for protein analysis. (B) Representative images of Western blots. Data are normalized to actin levels, and the WT group is set to 1 ( $\mathrm{n}=12-14$ per group).

Miwa et al., 2006; Tekinay et al., 2009). However, whether cognitive disturbances seen in AD patients are caused by alterations in Lynx protein function and/or expression is unknown. Here, we show that the level of PSCA protein is increased in the frontal cortex of AD patients. Combined with our finding that PSCA binds to the $\alpha 4$ nAChR subunit and inhibits nAChR signaling, increased PSCA levels may decrease $\mathrm{nAChR}$ function in patients with AD. If PSCA is able to inhibit the function of $\alpha 4 \beta 2 \mathrm{nAChRs}$ similar to Lynx1 (Ibanez-Tallon et al., 2002), the dysfunction of the receptor may have negative impact on the cognitive performance of the AD patients especially on attention and executive function as has been described previously (Okada et al., 2013; Sarter et al., 2009). Lypd6 also binds to nAChRs in human cortex (Thomsen et al., 2013) and is suggested as a nAChR neuromodulator (Darvas et al., 2009; Thomsen et al., 2013), but we found no change in Lypd6 levels in AD. Another member of the Lynx superfamily CD59, which is involved in the innate immune system as inhibitor of the membrane attack complex (Davies et al., 1989), has been demonstrated to be downregulated in AD (Yang et al., 2000). Alterations of both PSCA and CD59 in AD suggest that some Lynx proteins may be involved in the disease.

Therefore, we asked whether altered protein levels of PSCA are related to AD pathophysiology. We found increased PSCA protein levels in frontal cortex of $3 \times \mathrm{Tg}-\mathrm{AD}$ animals that overexpress $\mathrm{A} \beta$ and hyperphosphorylated tau, the hallmarks of $\mathrm{AD}$ pathology. This indicates that the combination of increased $A \beta$ and hyperphosphorylated tau are sufficient to increase in PSCA protein and suggest that the increase in PSCA levels found in AD patients is linked to the pathophysiology of AD. PSCA levels were not altered in transgenic Tg2576 mice that overexpress the A $\beta$ precursor APP and display increased $A \beta$ levels (Hsiao et al., 1996). This suggests that increased $A \beta$ levels are not sufficient to increase PSCA levels. However, it should be noted that APP transgene animal models, such as the $\operatorname{Tg} 2576$ mice, show a slower accumulation of $A \beta$ plaques than the $3 \times$ Tg-AD mouse model (reviewed by Lee and Han, 2013), so the lack of effect in the model may reflect lower $A \beta$ load. Furthermore, the progression and dynamics of $A D$ pathology in $3 \times \mathrm{Tg}-\mathrm{AD}$ mice are rather similar to the pathogenesis in $A D$ patients (Bilkei-Gorzo, 2014), where $A \beta$ deposition begins first in cortical regions and later in hippocampus, whereas tau pathology initiates in limbic regions and then progresses to cortical regions (Oddo et al., 2003). Here, we demonstrate by immunofluorescence labeling of frontal cortex and hippocampus from $3 \times \mathrm{Tg}-\mathrm{AD}$ mice a pronounced $\mathrm{AD}$-like pathology in 21-month-old animals, whereas 6-month-old animals are displaying intracellular $A \beta$ immunoreactivity but are devoid of amyloid plaques or apparent tau pathology suggesting that the changes in PSCA are not driven by tau pathology alone. Intracellular immunoreactivity in the young animals could indicate crossreactivity of the applied antibody 4G8 for APP as previously reported (Härtig et al., 2014; Winton et al., 2011). Because we show the strongest increase of PSCA levels in 6-month-old $3 \times \mathrm{Tg}$-AD mice, our data indicate that the regulation of PSCA levels occurs before A $\beta$ plaque and neurofibrillary tangle formation, although this does not preclude an involvement of soluble $A \beta$ forms in the regulation of PSCA levels. Because both A $\beta$ and PSCA can bind to $\mathrm{nAChRs,} \mathrm{they} \mathrm{may}$ share the same nAChR-binding site. However, it has been proposed that binding of $A \beta$ to different $n A C h R$ subtypes may involve different binding sites (Nery et al., 2013). Our data suggest that increase in PSCA may be a precursor to stages of plaque overload in the $3 \times \mathrm{Tg}-\mathrm{AD}$ mice, suggesting that the regulation of PSCA is an early event in the progression of AD pathology in this animal model.

Because PSCA binds to $\alpha 4$-containing nAChRs, the altered expression of $\mathrm{nAChRs}$ in $\mathrm{AD}$ could be a consequence of changes in PSCA or vice versa. We demonstrate that $\beta 2 \mathrm{nAChR}$ levels are decreased in frontal cortex of $A D$ patients and $3 \times \mathrm{Tg}-\mathrm{AD}$ mice, whereas they are not changed in Tg2576 animals and in the hippocampus of $3 \times \mathrm{Tg}-\mathrm{AD}$ mice, where we do not observe increased PSCA levels. However, when we investigated PSCA in PC12 cells, we did not find alterations of $\beta 2$ expression at both mRNA and protein levels in the absence or presence of PSCA, respectively. It should be noted that these findings do not exclude that PSCA is able to change $\beta 2$ expression in native tissue and/or under pathologic conditions. The finding that PSCA and $\beta 2 \mathrm{nAChR}$ levels are not increased in hippocampus of the $3 \times \mathrm{Tg}-\mathrm{AD}$ mice could be because of different origin of the cholinergic input to frontal cortex and hippocampus, respectively. Pathologic changes in the nuclei of the basal forebrain may therefore influence the expression of PSCA and $\beta 2$ nAChRs more prominently in the frontal cortex. Regulation of frontal cortical $\alpha 4 \beta 2 \mathrm{nAChR}$ expression in early-stage AD has previously been demonstrated in humans, for example, a significant reduction in $\alpha 4 \beta 2$ binding in vivo in frontal cortex of patients with mild cognitive impairment (Kendziorra et al., 2011) and early-stage AD, which correlated with high $\left[{ }^{11} \mathrm{C}\right]-\mathrm{PiB}$ uptake as a measure of amyloid deposits (Okada et al., 2013). In addition, [ $\left.{ }^{3} \mathrm{H}\right]$-nicotine autoradiography in postmortem frontal cortical tissue showed a significantly reduced binding in AD patients (Marutle et al., 2013). Given our data that PSCA binds to the $\alpha 4$ nAChR subunit, and the fact that $\alpha 4$ and $\beta 2 \mathrm{nAChR}$ subunits form heteromers, increased PSCA expression may influence $\alpha 4 \beta 2$ nAChR levels in AD. 
In summary, our findings have identified PSCA as a nAChRbinding protein in the human brain. PSCA inhibits nAChR signaling in vitro and is dysregulated in the frontal cortex of $A D$ patients as well as animal models with AD pathology. Therefore, PSCA-nAChR interactions may affect cognitive function particularly in the context of AD pathology.

\section{Disclosure statement}

The authors have no conflicts of interest to disclose.

\section{Acknowledgements}

The authors would like to thank Dr Cecilia Gotti (University of Milan, Milan, Italy) for kindly providing the $\beta 2$ antiserum, Drs Frank M. LaFerla and Salvatore Oddo (University of California, Irvine, CA) for breeding pairs of $3 \times \mathrm{Tg}-\mathrm{AD}$ and WT mice, Dr Carsten Hobohm (University of Leipzig, Germany) for funding the breeding of mice, Jesper F. Bastlund (H. Lundbeck A/S, Valby, Denmark) for providing tissue from Tg2576 and WT mice, and Dr Jens Grosche (Effigos, Leipzig) and Maria Nørnberg (NRU, Copenhagen, Denmark) for technical assistance. This work was supported by the Danish Strategic Research Council (COGNITO) and the Lundbeck Foundation.

\section{Appendix A. Supplementary data}

Supplementary data associated with this article can be found, in the online version, at http://dx.doi.org/10.1016/j.neurobiolaging. 2015.01.001.

\section{References}

Adams, J.P., Sweatt, J.D., 2002. Molecular psychology: roles for the ERK MAP kinase cascade in memory. Annu. Rev. Pharmacol. Toxicol. 42, 135-163.

Adermann, K., Wattler, F., Wattler, S., Heine, G., Meyer, M., Forssmann, W.G., Nehls, M., 1999. Structural and phylogenetic characterization of human SLURP1, the first secreted mammalian member of the Ly-6/uPAR protein superfamily. Protein Sci. 8, 810-819.

Auld, D.S., Kornecook, T.J., Bastianetto, S., Quirion, R., 2002. Alzheimer's disease and the basal forebrain cholinergic system: relations to beta-amyloid peptides, cognition, and treatment strategies. Prog. Neurobiol. 68, 209-245.

Bamezai, A., 2004. Mouse Ly-6 proteins and their extended family: markers of cell differentiation and regulators of cell signaling. Arch. Immunol. Ther. Exp. (Warsz) 52, 255-266.

Bilkei-Gorzo, A., 2014. Genetic mouse models of brain ageing and Alzheimer's disease. Pharmacol. Ther. 142, 244-257.

Braak, H., Braak, E., 1991. Neuropathological stageing of Alzheimer-related changes. Acta Neuropathol. 82, 239-259.

Braak, H., Braak, E., 1995. Staging of Alzheimer's disease-related neurofibrillary changes. Neurobiol. Aging 16, 271-278 discussion 278-284.

Buckingham, S.D., Jones, A.K., Brown, L.A., Sattelle, D.B., 2009. Nicotinic acetylcholine receptor signalling: roles in Alzheimer's disease and amyloid neuroprotection. Pharmacol. Rev. 61, 39-61.

Carson, R., Craig, D., Hart, D., Todd, S., McGuinness, B., Johnston, J.A., O’Neill, F.A., Ritchie, C.W., Passmore, A.P., 2008a. Genetic variation in the alpha 7 nicotinic acetylcholine receptor is associated with delusional symptoms in Alzheimer's disease. Neuromolecular Med. 10, 377-384.

Carson, R., Craig, D., McGuinness, B., Johnston, J.A., O’Neill, F.A., Passmore, A.P., Ritchie, C.W., 2008b. Alpha7 nicotinic acetylcholine receptor gene and reduced risk of Alzheimer's disease. J. Med. Genet. 45, 244-248.

Cook, L.J., Ho, L.W., Taylor, A.E., Brayne, C., Evans, J.G., Xuereb, J., Cairns, N.J., Pritchard, A., Lemmon, H., Mann, D., St Clair, D., Turic, D., Hollingworth, P., Moore, P.J., Jehu, L., Archer, N., Walter, S., Foy, C., Edmondson, A., Powell, J., Lovestone, S., Owen, M.J., Williams, J., Lendon, C., Rubinsztein, D.C., 2004. Candidate gene association studies of the alpha 4 (CHRNA4) and beta 2 (CHRNB2) neuronal nicotinic acetylcholine receptor subunit genes in Alzheimer's disease. Neurosci. Lett. 358, 142-146.

Court, J., Martin-Ruiz, C., Piggott, M., Spurden, D., Griffiths, M., Perry, E., 2001. Nicotinic receptor abnormalities in Alzheimer's disease. Biol. Psychiatry 49, 175-184.

Darvas, M., Morsch, M., Racz, I., Ahmadi, S., Swandulla, D., Zimmer, A., 2009. Modulation of the $\mathrm{Ca} 2+$ conductance of nicotinic acetylcholine receptors by Lypd6. Eur. Neuropsychopharmacol. 19, 670-681.

Davies, A., Simmons, D.L., Hale, G., Harrison, R.A., Tighe, H., Lachmann, P.J., Waldmann, H., 1989. CD59, an LY-6-like protein expressed in human lymphoid cells, regulates the action of the complement membrane attack complex on homologous cells. J. Exp. Med. 170, 637-654.

Davies, P., Feisullin, S., 1981. Postmortem stability of alpha-bungarotoxin binding sites in mouse and human brain. Brain Res. 216, 449-454.

Dorszewska, J., Florczak, J., Rozycka, A., Jaroszewska-Kolecka, J., Trzeciak, W.H., Kozubski, W., 2005. Polymorphisms of the CHRNA4 gene encoding the alpha4 subunit of nicotinic acetylcholine receptor as related to the oxidative DNA damage and the level of apoptotic proteins in lymphocytes of the patients with Alzheimer's disease. DNA Cell Biol. 24, 786-794.

Dubois, B., Feldman, H.H., Jacova, C., Dekosky, S.T., Barberger-Gateau, P., Cummings, J., Delacourte, A., Galasko, D., Gauthier, S., Jicha, G., Meguro, K., O’Brien, J., Pasquier, F., Robert, P., Rossor, M., Salloway, S., Stern, Y., Visser, P.J. Scheltens, P., 2007. Research criteria for the diagnosis of Alzheimer's disease: revising the NINCDS-ADRDA criteria. Lancet Neurol. 6, 734-746.

El Kouhen, R., Hu, M., Anderson, D.J., Li, J., Gopalakrishnan, M., 2009. Pharmacology of alpha7 nicotinic acetylcholine receptor mediated extracellular signalregulated kinase signalling in PC12 cells. Br. J. Pharmacol. 156, 638-648.

Fritz, B.A., Lowe, A.W., 1996. Polarized GP2 secretion in MDCK cells via GPI targeting and apical membrane-restricted proteolysis. Am. J. Physiol. 270, 176-183.

Gubbins, E.J., Gopalakrishnan, M., Li, J., 2010. Alpha7 nAChR-mediated activation of MAP kinase pathways in PC12 cells. Brain Res. 1328, 1-11.

Härtig, W., Saul, A., Kacza, J., Grosche, J., Goldhammer, S., Michalski, D., Wirths, O. 2014. Immunolesion-induced loss of cholinergic projection neurones promotes beta-amyloidosis and tau hyperphosphorylation in the hippocampus of tripletransgenic mice. Neuropathol. Appl. Neurobiol. 40, 106-120.

Hellstrom-Lindahl, E., Mousavi, M., Zhang, X., Ravid, R., Nordberg, A., 1999. Regiona distribution of nicotinic receptor subunit mRNAs in human brain: comparison between Alzheimer and normal brain. Brain Res. Mol. Brain Res. 66, 94-103.

Hruska, M., Keefe, J., Wert, D., Tekinay, A.B., Hulce, J.J., Ibanez-Tallon, I., Nishi, R. 2009. Prostate stem cell antigen is an endogenous lynx1-like prototoxin that antagonizes alpha7-containing nicotinic receptors and prevents programmed cell death of parasympathetic neurons. J. Neurosci. 29, 14847-14854.

Hsiao, K., Chapman, P., Nilsen, S., Eckman, C., Harigaya, Y., Younkin, S., Yang, F. Cole, G., 1996. Correlative memory deficits, Abeta elevation, and amyloid plaques in transgenic mice. Science 274, 99-102.

Ibanez-Tallon, I., Miwa, J.M., Wang, H.L., Adams, N.C., Crabtree, G.W., Sine, S.M. Heintz, N., 2002. Novel modulation of neuronal nicotinic acetylcholine receptors by association with the endogenous prototoxin lynx1. Neuron 33, 893-903.

Jurgensen, S., Ferreira, S.T., 2010. Nicotinic receptors, amyloid-beta, and synaptic failure in Alzheimer's disease. J. Mol. Neurosci. 40, 221-229.

Kawamata, J., Shimohama, S., 2002. Association of novel and established polymorphisms in neuronal nicotinic acetylcholine receptors with sporadic Alzheimer's disease. J. Alzheimers Dis. 4, 71-76.

Kendziorra, K., Wolf, H., Meyer, P.M., Barthel, H., Hesse, S., Becker, G.A., Luthardt, J., Schildan, A., Patt, M., Sorger, D., Seese, A., Gertz, H.J., Sabri, O., 2011. Decreased cerebral alpha4beta2* nicotinic acetylcholine receptor availability in patients with mild cognitive impairment and Alzheimer's disease assessed with positron emission tomography. Eur. J. Nucl. Med. Mol. Imaging 38, 515-525.

Laumet, G., Chouraki, V., Grenier-Boley, B., Legry, V., Heath, S., Zelenika, D., Fievet, N. Hannequin, D., Delepine, M., Pasquier, F., Hanon, O., Brice, A., Epelbaum, J., Berr, C., Dartigues, J.F., Tzourio, C., Campion, D., Lathrop, M., Bertram, L., Amouyel, P., Lambert, J.C., 2010. Systematic analysis of candidate genes for Alzheimer's disease in a French, genome-wide association study. J. Alzheimers Dis. 20, 1181-1188.

Laursen, B., Mork, A., Plath, N., Kristiansen, U., Bastlund, J.F., 2014. Impaired hippocampal acetylcholine release parallels spatial memory deficits in Tg2576 mice subjected to basal forebrain cholinergic degeneration. Brain Res. 1543, 253-262.

Lee, J.E., Han, P.L., 2013. An update of animal models of Alzheimer disease with a reevaluation of plaque depositions. Exp. Neurobiol. 22, 84-95.

Lyukmanova, E.N., Shenkarev, Z.O., Shulepko, M.A., Mineev, K.S., D’Hoedt, D. Kasheverov, I.E., Filkin, S.Y., Krivolapova, A.P., Janickova, H., Dolezal, V., Dolgikh, D.A., Arseniev, A.S., Bertrand, D., Tsetlin, V.I., Kirpichnikov, M.P., 2011 NMR structure and action on nicotinic acetylcholine receptors of water-soluble domain of human LYNX1. J. Biol. Chem. 286, 10618-10627.

Marutle, A., Gillberg, P.G., Bergfors, A., Yu, W., Ni, R., Nennesmo, I., Voytenko, L., Nordberg, A., 2013. (3)H-deprenyl and (3)H-PIB autoradiography show different laminar distributions of astroglia and fibrillar beta-amyloid in Alzheimer brain. J. Neuroinflammation 10, 90.

McKhann, G., Drachman, D., Folstein, M., Katzman, R., Price, D., Stadlan, E.M., 1984 Clinical diagnosis of Alzheimer's disease: report of the NINCDS-ADRDA Work Group under the auspices of Department of Health and Human Services Task Force on Alzheimer's Disease. Neurology 34, 939-944.

Meri, S., Lehto, T., Sutton, C.W., Tyynela, J., Baumann, M., 1996. Structural composition and functional characterization of soluble CD59: heterogeneity of the oligosaccharide and glycophosphoinositol (GPI) anchor revealed by laserdesorption mass spectrometric analysis. Biochem. J. 316 (Pt 3), 923-935.

Miwa, J.M., Freedman, R., Lester, H.A., 2011. Neural systems governed by nicotinic acetylcholine receptors: emerging hypotheses. Neuron 70, 20-33.

Miwa, J.M., Stevens, T.R., King, S.L., Caldarone, B.J., Ibanez-Tallon, I., Xiao, C., Fitzsimonds, R.M., Pavlides, C., Lester, H.A., Picciotto, M.R., Heintz, N., 2006. The prototoxin lynx1 acts on nicotinic acetylcholine receptors to balance neuronal activity and survival in vivo. Neuron 51, 587-600.

Miwa, J.M., Walz, A., 2012. Enhancement in motor learning through genetic manipulation of the Lynx1 gene. PLoS One 7, e43302.

Morishita, H., Miwa, J.M., Heintz, N., Hensch, T.K., 2010. Lynx1, a cholinergic brake, limits plasticity in adult visual cortex. Science 330, 1238-1240. 
Nakayama, H., Shimoke, K., Isosaki, M., Satoh, H., Yoshizumi, M., Ikeuchi, T., 2006. Subtypes of neuronal nicotinic acetylcholine receptors involved in nicotineinduced phosphorylation of extracellular signal-regulated protein kinase in PC12h cells. Neurosci. Lett. 392, 101-104.

Nery, A.A., Magdesian, M.H., Trujillo, C.A., Sathler, L.B., Juliano, M.A., Juliano, L., Ulrich, H., Ferreira, S.T., 2013. Rescue of amyloid-beta-induced inhibition of nicotinic acetylcholine receptors by a peptide homologous to the nicotine binding domain of the alpha 7 subtype. PLoS One 8, e67194.

Nordberg, A., Lundqvist, H., Hartvig, P., Lilja, A., Langstrom, B., 1995. Kinetic analysis of regional $(S)(-) 11 C$-nicotine binding in normal and Alzheimer brains-in vivo assessment using positron emission tomography. Alzheimer Dis. Assoc. Disord. 9, 21-27.

Oddo, S., Caccamo, A., Shepherd, J.D., Murphy, M.P., Golde, T.E., Kayed, R., Metherate, R., Mattson, M.P., Akbari, Y., LaFerla, F.M., 2003. Triple-transgenic model of Alzheimer's disease with plaques and tangles: intracellular abeta and synaptic dysfunction. Neuron 39, 409-421.

Okada, H. Ouchi, Y, Ogawa, M., Futatsubashi, M., Saito, Y Yoshikawa, E. Terada, T. Oboshi, Y., Tsukada, H., Ueki, T., Watanabe, M., Yamashita, T., Magata, Y., 2013. Alterations in alpha4beta2 nicotinic receptors in cognitive decline in Alzheimer's aetiopathology. Brain 136, 3004-3017.

Perry, E., Martin-Ruiz, C., Lee, M., Griffiths, M., Johnson, M., Piggott, M., Haroutunian, V., Buxbaum, J.D., Nasland, J., Davis, K., Gotti, C., Clementi, F., Tzartos, S., Cohen, O., Soreq, H., Jaros, E., Perry, R., Ballard, C., McKeith, I., Court, J., 2000. Nicotinic receptor subtypes in human brain ageing, Alzheimer and Lewy body diseases. Eur. J. Pharmacol. 393, 215-222.

Querfurth, H.W., LaFerla, F.M., 2010. Alzheimer's disease. N. Engl. J. Med. 362, $329-344$.

Reiter, R.E., Gu, Z., Watabe, T., Thomas, G., Szigeti, K., Davis, E., Wahl, M., Nisitani, S., Yamashiro, J., Le Beau, M.M., Loda, M., Witte, O.N., 1998. Prostate stem cell antigen: a cell surface marker overexpressed in prostate cancer. Proc. Natl. Acad. Sci. U. S. A. 95, 1735-1740.

Sarter, M., Parikh, V., Howe, W.M., 2009. nAChR agonist-induced cognition enhancement: integration of cognitive and neuronal mechanisms. Biochem. Pharmacol. 78, 658-667.

Schmittgen, T.D., Livak, K.J., 2008. Analyzing real-time PCR data by the comparative C(T) method. Nat Protoc 3, 1101-1108.
Schnell, S.A., Staines, W.A., Wessendorf, M.W., 1999. Reduction of lipofuscin-like autofluorescence in fluorescently labeled tissue. J. Histochem. Cytochem. 47 719-730.

Tekinay, A.B., Nong, Y., Miwa, J.M., Lieberam, I., Ibanez-Tallon, I., Greengard, P., Heintz, N., 2009. A role for LYNX2 in anxiety-related behavior. Proc. Natl. Acad. Sci. U. S. A. 106, 4477-4482.

Thomsen, M.S., Cinar, B., Jensen, M.M., Lyukmanova, E.N., Shulepko, M.A., Tsetlin, V., Klein, A.B., Mikkelsen, J.D., 2014. Expression of the Ly-6 family proteins Lynx1 and Ly6H in the rat brain is compartmentalized, cell-type specific, and developmentally regulated. Brain Struct. Funct. 219, 1923-1934.

Thomsen, M.S., Hansen, H.H., Timmerman, D.B., Mikkelsen, J.D., 2010. Cognitive improvement by activation of alpha7 nicotinic acetylcholine receptors: from animal models to human pathophysiology. Curr. Pharm. Des. 16 323-343.

Thomsen, M.S., Jensen, M.M., Cinar, B., Wang, H., Gondré-Lewis, M.C., Klein, A.B. Mikkelsen, J.D., 2013. Perinatal Nicotine Administration Increases Hippocampal Lypd6 Levels in Adulthood Program No. 702.09. 2013 Neuroscience Meeting Planner. Society for Neuroscience, San Diego, CA. Online.

Thomsen, M.S., Mikkelsen, J.D., 2012. The alpha7 nicotinic acetylcholine receptor complex: one, two or multiple drug targets? Curr. Drug Targets 13 $707-720$.

Tsetlin, V., 1999. Snake venom alpha-neurotoxins and other 'three-finger' proteins Eur. J. Biochem. 264, 281-286.

Wang, H.Y., Lee, D.H., Davis, C.B., Shank, R.P., 2000. Amyloid peptide abeta(1-42) binds selectively and with picomolar affinity to alpha7 nicotinic acetylcholine receptors. J. Neurochem. 75, 1155-1161.

Winton, M.J., Lee, E.B., Sun, E., Wong, M.M., Leight, S., Zhang, B., Trojanowski, J.Q. Lee, V.M., 2011. Intraneuronal APP, not free abeta peptides in 3xTg-AD mice: implications for tau versus abeta-mediated Alzheimer neurodegeneration. J. Neurosci. 31, 7691-7699.

Yang, L.B., Li, R., Meri, S., Rogers, J., Shen, Y., 2000. Deficiency of complement defense protein CD59 may contribute to neurodegeneration in Alzheimer's disease. J. Neurosci. 20, 7505-7509.

Zhang, Y., Lang, Q. Li, J., Xie, F., Wan, B., Yu, L., 2010. Identification and characterization of human LYPD6, a new member of the Ly-6 superfamily. Mol. Biol. Rep. 37, 2055-2062. 